\title{
Justifications for Undertaking Marketing Orientation Studies in Higher Learning Institutions in Tanzania
}

\author{
Francis Muya * \\ National Institute of Transport \\ Dar es Salaam, Tanzania
}

\author{
Hawa Tundui \\ Mzumbe University \\ Morogoro, Tanzania
}

\begin{abstract}
This paper was written with the major aim of presenting a number of issues which justify the undertaking of marketing orientation studies in Tanzania Higher Learning Institutions (HLIs). It was also the intention of the authors to give a brief picture of marketing practice in Tanzania environment and on the higher learning institutions. The information used in this paper was mainly collected through review of literatures on articles which focused on marketing orientation and higher learning institutions. The review of literature revealed that different aspects including challenges facing HLIs, sectoral variation, geographical concentrated literatures, qualitative based studies, review of literature based studies, single informants responses, small samples problems and limited responses limitations are major issues justifying undertaking a marketing orientation study in Tanzania HLIs.
\end{abstract}

Keywords: Marketing; Privatisation; Reform.

\section{$1 \quad$ Introduction}

The environment surrounding Higher Learning Institutions (HLIs) is comprised of different forces and changes including high competition, increased globalisation of education, increased societal expectations, and reduced government subsidies (Beneke \& Human, 2010; Hussin, Soon \& Sidin, 2000; Marginson, 2004; Starck \& Zadeh, 2013; United Republic of Tanzania (URT), 2000).

In relation to competition, government owned HLIs are not the only providers of higher education. The mix of Tanzania HLIs is comprised of government, nongovernment religious, and non-government non-religious. Considering that

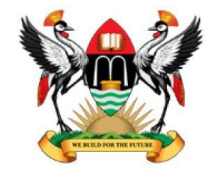

East African School of Higher Education Studies \& Development, Makerere University
Makerere Journal of Higher Education ISSN: 1816-6822 (Print); 2707-6113 (Online) 11 (2) (2019) $171-188$

DOI: http://dx.doi.org/10.4314/majohe.v11i2.7

(C) The Author(s) 2019

Reprints \& permission: EASHESD

http://ajol.info/majohe

Conflict of interest: None

Funding: None

\footnotetext{
* Corresponding author: mgosimuya@gmail.com.
}

Cite article as: Muya, F, Tundui, H. (2019). Justifications for Undertaking Marketing Orientation Studies in Higher Learning Institutions in Tanzania. Makerere Journal of Higher Education, 11 (2), 171-188. http://dx.doi.org/10.4314/majohe.v11i2.7 
different factors influence the choice of course and college of study, government HLIs cannot claim that they cannot have any enrolment problems. Enrolment is however a critical problem in Tanzania private HLIS. Even if enrolment may not be a problem, retention is among the major problems facing HLIs to date. This view is supported by American Federation of Teachers (AFT) (2011) which affirmed that the number of students with college education is not as high as it should be, and college student retention rates are not as high as any educator would want them to be. HLIs must therefore have strong strategies in place in order to fight enrolment and retention problem.

The boarders of providing domestic higher education are slowly eroding. Due to globalization, domestic higher learning institutions not only compete with domestic universities but also with international universities and colleges. In recent years it is common to find HLIs in Tanzania with Korean affiliations (United African University of Tanzania), with Indians Affiliation (St. Joseph University in Tanzania) and those originating from nearby East African Countries (Kampala International University Dar es Salaam College-from Uganda). Another indicator of globalization of higher education in Tanzania are exhibitions organized by TCU taking place every year. Such exhibitions include participants from both local and International HLIs. Specific organizations have been established in Tanzania which connects students with different HLIs worldwide. According to URT (2000) globalisation have reduced the need for learners to assemble in one place over a specified period in order to learn through distance learning. On other hand flexible training has been introduced and learners need to be equipped with a wide range of skills and to prepare them for a rapidly changing labour market. All these indicate that the boundaries of providing domestic higher learning education are disappearing slowly imposing some pressures on local HLIs. Due to globalization of education, the tasks are not such limited but extends on what measures and strategies can be institutionalized to make them competitive in such a challenging environment. This view is line with various people such as (Bloom, Canning \& Chan, 2006) who underscore that knowledge-based competition within a globalizing economy is prompting a fresh consideration of the role of higher education in development and growth.

Than increased competition and Globalisation, Tanzania HLIs and even globally are facing economic and financial strains. Economically, the dictates of structural adjustment, subsuming budgetary cuts and discipline, cost sharing and diminished role of the state and international institutions are real and compelling (URT, 2000). For example from 1985 to 1989, 17 per cent of the World Bank's worldwide education-sector spending was on higher education. But from 1995 to 1999, the proportion allotted to higher education declined to just 7 per cent (Bloom, Canning \& Chan, 2006). Higher education in Africa has suffered from such reductions in spending. Financing of education in Tanzania suffer the same trend, as its pattern is not stable and has been hit much by this trend. In the financial year 2012/2013, 719.8 billion were set for financing higher education. In 2013/2014 the amount 
declined up to 526.7, a decrease of 26.82 per cent from the 2012/2013 figure. The financing became worse in $2014 / 2015$ when the amount set dropped up to 311.3 billion. The amount was raised slightly in 2015/2016 (URT, 2015). Such findings show how higher education and its institutions are increasingly marginalized by government financing year after year.

In addition to the changes mentioned above, Tanzania HLIs and global ones have different challenges including, low general gross enrolment (GUNI, 2007), bad image due to low quality education, receiving only domestic students despite presence of courses which can attract international students, limited finance for their operations, production of unemployable graduates and low university and technical higher education coverage (Ishengoma, 2008; Mpanju, 2012; Ndyali, 2016; URT, $2010,2011,2014,2016)$. In overall terms, Tanzania is performing poorly in higher education and training component as revealed by Global Competitiveness Report (2017/2018), where the country is ranked 130 out of 137 scoring 2.6 out of 7 scores in Higher Education and Training sub index (Klaus, 2017).

\section{Coping Mechanism}

Taking into account of the changes and forces in the environment where HLIs operates, being marketing oriented is seen as a best strategy which can enable HLIs to survive in such a complicated environment. According to Sharp (2007) marketing orientation currently holds the place of leading modern business philosophy throughout the world's major corporations and leading business schools. Unless business schools succeed in improving their marketing, they will stand accused of not practicing what they preach.

Maringe (2006) espouse that the trends in the environment in which HLIs operate, have varying effect on them hence a driving force for the marketization of higher education. Rindfleish (2003) adds that with such forces, the sustainability of HLIs is questionable creating a need for adopting marketing oriented approaches and techniques as those applied in profit organisations. As competition among higher education institutions for students and resources intensifies, admissions and enrolment management administrators continue to view marketing techniques, strategies and activities that allow a better understanding of customers and competitors as valuable resources (Dolnicar \& Lazarevski, 2009; Newman, 2002). This view is supported by Stachowski (2011) that as in other sectors where there is competition, there is marketing, so long as HLIs face competition, marketing is an unavoidable practice.

Andreasen and Kotler (2003) argue that decrease in support from traditional sources, such as government, has emphasised the importance for non-profit organizations to apply marketing principles by making use of a proper philosophy 
of marketing, systematic approach to solving marketing problems, awareness and ability to use the very latest concepts and techniques from the private sector.

\section{$3 \quad$ What is Marketing Orientation?}

Marketing orientation refer to the set of beliefs that shapes particular attitudes and culture of business (Salyovaa et al., 2015). The phrase is closely related with "market orientation" which can be traced from two famous sources of Narver and Slater (1990) and Kohli and Jaworski (1990). According to Narver and Slater (1990) market orientation is a culture within organisations that most effectively and efficiently creates the necessary behaviours for the creation of superior value for buyers and, thus continuous superior value for the business. Kohli and Jaworski (1990) view market orientation as the implementation of the marketing concept philosophy, which is centred on customer needs and organisation profits. They define market orientation as the organisation wide generation of market intelligence pertaining to current and future customer needs, dissemination of the intelligence across departments, and organisation-wide responsiveness to it. Hemsley-Brown and Oplatka (2010) view market orientation as the degree to which an organisation generates and uses intelligence about the current and future needs of customers; develops a strategy to satisfy these needs; and implements that strategy to meet those needs and wants.

Market orientation is conceptualised as an extension to the marketing concept as it magnifies the focus from being customer-centred to being market centred, including various stakeholders especially competitors, customers and factors outside organisations affecting customer needs (Goldman \& Grinstein, 2010; Hunt \& Morgan, 1995; Kohli \& Jaworski, 1990; Narver \& Slater, 1990). According to Levitt (1960) the concept of market orientation is the heart of marketing theory. This is supported by various authors such as (Goldman \& Grinstein, 2010; Kirca, Jayachandran \& Bearden, 2005; Kohli \& Jaworski, 1990) who view it as a corner stone of the marketing management involving the implementation of the marketing concept. According to Sharp (1991), marketing orientation recognises the concept of consumer sovereignty and that consumption is the sole purpose of production, but it also recognises that a firm is free to pick who its customers are. A firm with a marketing orientation chooses its markets and manages its own productive capabilities in order to achieve its goals. Marketing orientation goes beyond a market orientation in that it considers information in the marketplace which is relevant, "where relevance is a function of the organisation's, not the market's, characteristics" (Sharp, 1991). According to Kurtinaitiene (2005) marketing orientation (sometimes called market orientation) contributes to the understanding and implementation of the marketing concept.

The two phrases "market orientation" and "marketing orientation" are sometimes used interchangeably as done by various authors including (Kohli \& 
Jaworski, 1990; Kurtinaitienè 2005; Tajeddini, Trueman \& Larsen, 2006; Šályováa et al., 2015). The phrase marketing orientation is adopted in this paper. Šályováa et al., (2015) view marketing orientation usage as a proper phrase due its wide utilisation and linguistically referring to the marketing concept. In this study marketing orientation is therefore treated as synonymous with undertaking marketing activities as well as application of marketing principles.

\section{$4 \quad$ Why Marketing Orientation?}

Through marketing orientation, HLIs can obtain a wide array of benefits to themselves, students and the public they serve at large. Marketing orientation brings in sources of funding and competes for the funds granted by public and private sectors and compete for potential students (Caruana, Ramaseshan \& Ewing, 1998; Svenson \& Wood, 2007). Narver and Slatter (1990) found substantial effect of market orientation on profitability among different types of business.

Following marketing concept or being marketing oriented is associated with many other benefits including making a great difference in the ability of organisations to meet their service objectives including delivering quality services (Luk, 1997; Kurtz, 2008; SeyedJavadin, Estiri \& Aghamiri 2012; Voon, 2006). It enables firms to be innovative and hence competitive both domestically and internationally (Hemsley-Brown \& Oplatka, 2006; Maringe, 2004, 2005; Tajeddini, Trueman \& Larsen, 2006). It is a way to reach the institutional goals such as surviving as organisation, increasing its professional reputation, improving facilities and faculty and developing enrolment and endowment (Ivy, 2001; Nguyen \& LeBlanc, 2001; Polat \& Umit, 2010); and adapting to demands in the society (Caruana et al., 1998). In the view of Rowley (2003), marketing can enable an organisation to have a loyal customer, and for businesses like Higher Education Institution (HEI), a loyal customer base leads to enhanced success and lowering higher investments of capturing new ones. The author is supported by others like (Ackerman \& Schibrowsky, 2007; Lichiello, 2014 \& Shepherd, 2008) who view marketing as essential in retaining students.

According to Stachowski (2011) being marketing oriented leads to fulfilment of the mission of the institution, improved satisfaction of staff and learners and the ability to attract greater resources, both financial and non-financial.

Moorman and Rust (1999) found that marketing function contributes to perceptions of firm financial performance, customer relationship performance, and new product performance beyond that explained by a firm's market orientation. For service firms, the value of the marketing function also is related positively to marketing ability to connect the customer to service delivery. These findings are in line with those of Zhang et al. (2017) who found that implementation of a market orientation leads to improved financial and marketing performance. Momrak (2012) 
also found a direct effect of market orientation on business performance in terms of profitability. The findings are in line with those of Tajeddini, Trueman and Larsen (2006) who found that customer orientation has a positive effect on performance as well as the level of innovativeness in each company.

\section{$5 \quad$ Marketing Practice and Orientation in Tanzania HLIs}

In Tanzania marketing is not a new phenomenon. It is however highly dominant in for profit organisation than in non-profit organisations such as HLIs. The state of marketing in Tanzania HLIs is not quite different as espoused by different authors that press release, public relations, advertisement attracting applications, education fairs and exhibitions and other means of communication remain the focus of many educational institutions' marketing activities (Ivy, 2002; Nicolescu, 2009;Young, 2005; Tabaku \& Mersini, 2013).

As said above, marketing in the profit organisations is very dominant as revealed by different practices in different industries. Marketing is carried out by different players operating in different industries including telecommunications, beverage industry, hotel industry, media industry, banking industry, and manufacturing industry.

Most of organisations operating in those industries/sector have marketing directorates (Tanzania Breweries Limited [TBL], 2016; Vodacom, 2017; Tanzania Cigarette Company [TCC], 2015) and large budgets are set aside for marketing activities (CRDB Bank, 2015) which is an indication of the value placed on marketing functions by these organisations. Due recent trends in the business, Chartered institute of Marketing (CIM) (2015) argue that what was once seen as a departmental activity is now regarded as a frontline business attitude for all employees.

Marketing in Tanzanian organisations take different forms like new product development and launching (TCC introduction of Camel Black and White in the premium segment and Portsman mini in the value segment in year 2015, introduction of $3 \mathrm{G}$ and $4 \mathrm{G}$ mobile services and wireless broadband networks by telecommunications companies, Vodacom value added services like M-Paper and International Money Transfers (IMT) (Vodacom, 2017). Other forms includes, price setting and adjustments (TBL, 2015), sponsorship activities, communication campaigns at point of sale, thematic campaigns, consumer activations, contests, challenges and awards, distribution optimisation initiatives, opening of new depots and retail uptake promotion (TCC, 2015; Vodacom, 2017; TBL, 2015). At the National Microfinance Bank (NMB), marketing take different forms. From their mission statement which is "through innovative distribution and its extensive branch network, NMB offers affordable customer focused, financials" which indicates that the bank is more customer focused than organisational focused. The banks segments its markets into a group of wholesale segments (which includes 
corporate, institutional, government (local/ central), transactional services and Trade) and retail segments (which includes personal banking, civil servants and micro and Small and Medium Enterprises (SMEs) segments). The bank undertakes different campaigns and have self-service channels and a wide distribution network of Automated Teller Machines (ATMs) and branches throughout the country (Wiessing, 2014).

Marketing is playing a great role in these companies. It is a reason why customers consume their products (Hales et al., 2004). It is viewed as a means of improving company's capability and ability to improve its total service to retailers (TBL, 2008). Marketing is also recognised in building brands and royal customer base intangible assets that make up a large percentage of the value of a firm (Kotler et al., 2009).

\section{$6 \quad$ Methodology}

This paper was written based on review of 101 works on marketing orientation and issues connected with higher learning institutions ranging from journal papers, company annual reports, government publications and thesis and dissertations published between 1990 and 2018. The corresponding author did this on the course of developing his $\mathrm{PhD}$ proposal and decided to present his major findings from literature review in order to enlighten other $\mathrm{PhD}$ candidates on a number of gaps which can justify the undertaking of research in the areas where gaps where identified. The author's own $\mathrm{PhD}$ work is intended to fill some of the gaps identified.

\section{Justifications for Marketing Orientation Studies}

The following points reveal the justifications for undertaking marketing orientation studies in Tanzania HLIs.

\subsection{Challenges Facing HLIs}

It is beyond reasonable doubt that HLIs in Tanzania and globally are facing a multitude of challenges. HLIs in Tanzania are facing low general gross enrolment, bad images due to low quality education, receiving only domestic students despite presence of courses which can attract international students, limited finance for their operations, production of unemployable graduates and low university and technical higher education coverage (Ishengoma, 2008; Mpanju, 2012; Ndyali, 2016; URT, 2010, 2011, 2014, 2016). In overall terms, Tanzania is performing poorly in higher education and training component as revealed by Global Competitiveness Report (2017/2018), where the country is ranked 130 out of 137 by scoring 2.6 out of 7 in 
Higher Education and Training sub index (Klaus, 2017). The stated weaknesses in higher education are contrary to the University Act, 2005, University Act (General Regulations), 2013, Education and Training Policy (2014), Vision 2025 and even the Sustainable Development Goals (SDGs), which all emphasize the need for improved quality education as well as increased access and equity to higher education. The only way to cope with such challenges is to be marketing oriented which will enable HLIs to enjoy multiple benefits ((Dolnicar \& Lazarevski, 2009; Newman, 2002; Hammond, Webster \& Harmon, 2006; Svenson \& Wood, 2007; Shepherd, 2008; Ivy, 2001; Nguyen \& LeBlanc, 2001).

\subsection{Marketing Orientation Centrality}

Being marketing oriented is unavoidable in the current age given a bundle of benefits associated with this strategy. According to Sharp (2007) market orientation currently holds the place of leading modern business philosophy throughout the world's major corporations and leading business schools. Unless business schools succeed in improving their marketing, they will stand accused of not practicing what they preach.

\subsection{Regulatory Requirements}

Higher Learning Institutions governing bodies such as Tanzania Commission for Universities (TCU), National Council for Technical Education (NACTE) and InterUniversity Council for East Africa (IUCEA), requires institutions under their jurisdiction to undertake self-assessment for the purpose of understanding their quality (IUCEA, 2014, NACTE, nd, TCU, 2014). A marketing orientationperformance study is a reminder for those institutions who do not undertake such a self-study. It is also a broad, an organization wide and comprehensive guidance on what form a self-assessment process can take. This is in line with the views of Ravi, Mansureh \& Janelle (2016) and URT $(2005,2013)$ that underscore "self-study" of HLIs to assess their role in society as effective knowledge-transfer entities.

\subsection{Sectoral Variation in Marketing Orientation Studies}

Sector-wise, most of the studies in market orientation were in the profit sector rather than in non-profit sector (Dolnicar \& Lazarevski, 2009; Tabaku, 2013; Pope et al., 2009), few in general non-profit organisations (Brady et al., 2011; Dolnicar \& Lazarevski, 2009) and some in HLIs (Ackerman \& Schibrowsky, 2007; Lichiello, 2014; Rowley, 2003; Shepherd, 2008). In Tanzania almost all studies on marketing and market orientation were done in the profit sector (Jaensson \& Uiso, 2015; and Meitamei, 2009 (all these studied market orientation and others including Njawa, 2015; Singumlanji, 2009 based on general marketing). Studies on HLIs do exists, but were carried out in different topics (Bastos \& Rebois, 2011 (performance of HLIs 
in science, technology and innovation); Buxay, 2013 (challenges facing HLIs in income generation); Kipesha \& Msigwa, 2013 (efficiency of HLIs); ole Gabriel, 2005 (value co-creation and delivery systems in HLIs); and URT, 2000 (challenges of education). To carry a study on the relationship between marketing orientation and HLIs performance in Tanzania environment is therefore justifiable given this sectoral gap.

\subsection{Geographical Concentrated Marketing Orientation Literature}

Geographically, most of studies on marketing orientation were conducted in other countries outside Africa. Few were carried in Africa (Akomea \& Yeboah, 2011; Burgess \& Nyajeka, 2007; Mahmoud, Blankson, Owusu-Frimpong, Nwankwo \& Trang, 2016; Maringe, 2005) and very few in Tanzania (Daulinge, 2009; Jaensson \& Uiso, 2015; Meitamei, 2009). A study on the relationship between marketing orientation and HLIs performance is crucial in order to contribute to a worldwide discussion of marketing orientation on HLIs and other non-profit organisations hence adding new knowledge on the area which is limited and even lacking in Tanzania. The role of marketing orientation cannot be generalised across sectors and countries with different economic, political and cultural structure.

\subsection{Variations in Research Methodology}

\subsubsection{Qualitative Based Studies}

Some previous studies on marketing orientation were purely qualitative (Beck, 2015; Hannover, 2014) with findings which were seen as being weak in reliability and possibility to limit availability of more insight, expanded understanding of the studied research problem and difficult in making statistical comparisons (Babbie, 2007; Creswell, 2009). Other studies were purely quantitative. Such situation calls for a mixed method study which will combine both qualitative and quantitative approaches. Baskarada and Koronios (2018) view mixed approach research as the type of research in which a researcher or team of researchers combines elements of qualitative and quantitative research approaches, for the broad purposes of breadth and depth of understanding and corroboration. Creswell (2009) argue that mixed method approach make possible the use of both approaches in tandem so that the overall strength of a study is greater than either qualitative or quantitative research. Other advantages of mixed approaches is the potential for gaining a fuller, richer and more complete understanding of a research question with a potential disadvantage of lengthy data collection and analysis phases required and demand placed on the researcher to be expert in the use of both quantitative and qualitative approaches (Jupp, 2006). 


\subsubsection{Literature Based Studies}

Other previous studies on marketing orientation were purely review of literature based studies (Akonkwa, 2009; Canterbury, 2000; Gibbs, 2011; Rotfeld, 2008). Such studies only provide limited findings on marketing of HLIs and information from literature review may also be outdated and may partially address the research questions and objectives (Saunders, Lewis \& Thornhill, 2007). A study which combine both literature review findings and fresh views collected from the field is important to solve limitations associated with literature reviews.

\subsubsection{Single Informant Researches}

A number of studies were carried out using single group of informant/respondent (Zebal \& Goodwin, 2012; Newman 2002; Polat \& Donmez 2010; Voon 2008; McGrath 2002) and these authors complained that their studies posed the problem of absence of generalisability of the findings to other industry contexts and common method bias problems on the results hence advising studies which will involve multi respondents.

\subsubsection{Small Samples Problem}

A number of studies were carried out using small samples (Beck, 2015-two universities; Lwiza and Nwankwo, 2002-nine (9) respondents; Meitamei, 2010-one bank; Nicolescu et al., 2013-one university). The authors advised future research to use large samples which could be representative of the population in the areas of study, possibility to include critical and key informers who might be viable in providing market-oriented related information, avenue for enhancing enhance the generalisability of the conclusions and overcome other problem like failure to permit statistical analysis of the relationship between variables associated with small sample researches.

\subsubsection{Limited Responses Limitation}

A number of studies on marketing orientation complained of limited response problems (Ross, Grace \& Shao, 2013-where the resultant sample of useable surveys was 159 , representing a response rate of 26.1 per cent; Maydeu-Olivares \& Lado, 2003-where 122 valid questionnaires were obtained, giving a response rate of 22 percent; Pope et al., 2009 where the response rate was 3.8 per cent; Goetz Hoelter $\&$ Krafft, 2013 who obtained a response rate of about 20 percent). The major reason cited by these authors was the use of mailed questionnaires. It was advised that future research use data collection methods which can facilitate high responses rates. 


\section{Conclusion and Recommendations}

We have presented the state of marketing in Tanzania environment and the justifications for undertaking marketing orientation studies in Tanzania HLIs. It is the belief of the authors that this paper will now open the path for those who want to undertake a study on such a topic in such an environment. The justifications are not only for studies in this topic and in this environment only, but studies in any topic and in any environment can justifiably be undertaken based on the findings presented in this paper. Carrying a study because of a particular problem only, because of geographical factors only, because of sectoral variations only, or because of methodological variations only, are weak justifications for studies efforts.

Future research can now be done to fill the gaps stated in this paper. This can have a number of benefits including expansion of marketing orientation knowledge, tapping of marketing orientation associated benefits, improved validity and reliability of the future research findings and high responses rates.

\section{References}

Ackerman, R., \& Schibrowsky, J. (2007). A business marketing strategy applied to student retention: A higher education initiative. Journal College Student Retention, 9(3), 307-336. doi.org/10.2190/CS.9.3.d

Akomea, S.Y., \& Yeboah, G. (2011). Market orientation and firm performance in Ghana's pharmaceutical industry. Journal of Science and Technology, 3(2), 109-119. doi.org/10.4314/just.v31i2.69399.

Akonkwa, D.B.M. (2009). Is market orientation a relevant strategy for higher education institutions? Context analysis and research agenda. International Journal of Quality and Service Sciences 1(3), 311-333. doi.org/10.1108/17566690911004230

Andreasen, A.R., \& Kotler, P. (2003). Strategic marketing for non-profit organisations (6 $6^{\text {th }}$ Ed.). New Jersey: Prentice Hall.

Babbie, E. (2007). Practice of social research (11 th ed). United States of America: Thomson Vvadsvvorth.

Baskarada, S., \& Koronios, A. (2018). A philosophical discussion of qualitative, quantitative, and mixed methods research in social science. Qualitative Research Journal, https://doi.org/10.1108/QRJ-D-17-00042.

Bastos, C.A., \& Rebois, R.R. (2011). Review and evaluation of the performance of Tanzania's higher education institutions in science, technology and innovation: Final Report. Working paper 9. http://www.unesco.org/new/fileadmin/MULTIMEDIA/HQ/SC/pdf/s

Beck, C. N. (2007). A Review of market orientation practices for selected public Carnegie high research activity institutions. A dissertation submitted in partial fulfilment of the requirements for the degree of Doctorate of Education in 
Higher Education Administration Montana State University, Bozeman, Montana. https://studylib.net/doc/13550374.

Beneke, J., \& Human, G. (2010). Student recruitment marketing in South Africa: An exploratory study into the adoption of a relationship Orientation. African Journal of Business Management, 4(4), 435-44. open.uct.ac.za/bitstream/item/19028/

Bloom, D., Canning, D., \& Chan, K. (2006). Higher education and economic Development in Africa. Harvard University. http://ent.arp.harvard.edu/.

Brady, E., Jan, B., Brennan, L., \& Conduit. J.J. (2011). Market orientation and marketing in non-profit organisations: Indications for fundraising from Victoria. International Journal of Nonprofit and Voluntary Sector Marketing, 16(1), 84-98. doi.org/10.1002/nvsm.403.

Burgess, S.M., \& Nyajeka, P. (2007). Market orientation and performance in lowincome countries: The case of Zimbabwean retailers. In J. Antonio Rosa \& M. Viswanathan (eds.), Product and market development for subsistence marketplaces. Advances in International Management. Emerald Group Publisbing Limited, 215-257.doi/abs/10.1016/S1571-5027\%2807\%2920010-5

Buxay, B.T. (2013). Assessment of challenges facing higher learning institutions in income generation in Tanzania. A Dissertation submitted in partial fulfilment of the requirements for the award of the degree of Master of Business Administration (MBA-CM) of Mzumbe University. Retrieved from scholar.mzumbe.ac.tz/handle/11192/506.

Canterbury, R.M. (2000). Higher education marketing: A challenge. Journal of Marketing for Higher Education, 9(3), 15-24. doi/abs/10.1300/J050v09n03_02

Caruana, A., Ramaseshan, B., \& Ewing, M.T. (1998). Do universities that are more market orientated perform better?” International Journal of Public Sector Management, 11(1), 55-70. https://doi.org/10.1108/09513559810199898.

Chartered Institute of Marketing (CIM). (2015). A Brief summary of marketing and how it works. Berkshire, L6 9QH. United Kingdom. https://www.cim.co.uk/media/4772/7ps.pdf.

CRDB Bank Plc. (2015). Annual report and financial statements for the year ended 31st December 2015. https://www.dse.co.tz/.../CRDB\%20.

Creswell, J.W. (2009). Research Design: Qualitative, Quantitative, and Mixed Methods Approaches ( $3^{\text {rded}}$ ). Singapore: SAGE Publications Asia-Pacific Pte. Ltd.

Dolnicar, L., \& Katie, S. (2009). Marketing in non-profit organizations: An international perspective. International Marketing Review, 26(3), 275-291. doi.org/10.1108/02651330910960780.

Gibbs, P. (2011). An Aristotelian model for ethical higher education marketing: The role of practical wisdom. Journal of Marketing for Higher Education, 21(3), 203-214. doi/abs/10.../08841241.2011.623732.

Global University Network for Innovation (GUNI). (2007). Higher Education in the World. New York: Palgrave McMillan. 
Goetz, O. H. A. \& Krafft, M. (2013). The role of sales and marketing in marketoriented Companies. Journal of Personal Selling \& Sales Management, 3(4), 353-371. doi/abs/10.../PSS0885-3134330401.

Grinstein, A., \& Amir, G. (2010). Stages in the development of market orientation publication activity. European Journal of Marketing, 4(9/10), 26. DOI: 10.1108/03090561011062899.

Hammond, K., Webster, R. L. \& Harmon, H. A. (2006). Market orientation, top management emphasis, and performance within university schools of business: Implications for universities. Journal of Marketing Theory and Practice, 4(1), 69-85. doi.org/10.2753/MTP1069-6679140105.

Hemsley-Brown, J., \& Oplatka, I. (2010). Market orientation in universities: A comparative study of two national higher education systems. International Journal of Educational Management, 24(3), 17. DOI: 10.1108/09513541011031565.

Hunt, S.D., \& Morgan, R. M. (1995). The comparative advantage theory of competition. Journal of Marketing, 59, 1-15. DOI: 10.2307/1252069.

Hussin, S.R., Ho Soon, T., \& Sidin, S.M. (2000). Marketing analysis of the higher education service sector in Malaysia: Consumer perspective Pertanika J. Soc. Sci. and Hum, 8(1), 1-6. http://psasir.upm.edu.my/id/eprint/3290/1/.

Inter-University Council for East Africa (IUCEA). (2014). Principles and Guidelines for Quality Assurance in Higher Education in East Africa, Kampala.

Ishengoma, J.M. (2008). Financing public higher education in Tanzania: Towards a new model and implications for development and retention of the next generation of academics, Paper presented at the University Leaders' Forum: Next Generation of Academics, Accra, Ghana. www.foundationpartnership.org/.../presentations/.../S4_Ishengoma.

Ivy, J. (2001). Higher education institution image: A Correspondence analysis approach. The International Journal of Educational Management, 15(6), 276-82. doi.org/10.1108/09513540110401484

Jaensson, J., \& Uiso, U. (2015). Assessing the link between market orientation and poverty reduction in the tourism Industry: The case of Tanzania. International Journal of Business Tourism and Applied Sciences, 3(1).http://www.ijbtsjournal.com/images/column.

Jupp, V. (2006). The Sage dictionary of social research methods. 1 Oliver's Yard 55 City Road London EC1Y 1SP: SAGE Publications Ltd.

Kipesha, E.F., \& Msigwa, R. (2013). Efficiency of Higher Learning Institutions: Evidences from Public Universities in Tanzania. Journal of Education and Practice, 4 (7). https://www.researchgate.net.

Kirca, A.H., Jayachandran, S., \& Bearden, W.O. (2005). Market orientation: A metaanalytic review and assessment of its antecedents and impact on performance. Journal of Marketing, 69(2), 24-41. https://doi.org/10.1509/jmkg.69.2.24.60761

Klaus, S. (2017). The global competitiveness report 2017-2018. Geneva: World Economic Forum. https://www.scribd.com/document. 
Kohli, A.K., \& Jaworski, B.J. (2010). Market orientation: The construct, research propositions, and managerial implications. Journal of Marketing, 54, 18. DOI: $10.2307 / 1251866$.

Kotler, P., Keller, K.L., Brady, M., Goodman, M., \& Hansen, T. (2009). Marketing Management. Harlow: Pearson Education Limited.

Kurtinaitiene, J. (2005). Marketing orientation in the European Union mobile telecommunication market. Marketing Intelligence and Planning, 23(1):104-113, https://doi.org/10.1108/02634500510577500.

Levitt, T. (1960). Marketing myopia. Harvard Business Review July / August. 4556.https://manchester.rl.talis.com/items/E63A8318-C798-56F6-80A8 600F1FCFD5AE.

Lichiello, P.C. (2014). The graduate retention relationship cycle: The role of performance, engagement, satisfaction, and alienation. Lynchburg College. Theses and Dissertations. Paper 1. https://digitalshowcase.lynchburg.edu/etd/1.

Luk, S.T.K. (1997). An Examination of the role of marketing culture in service quality. International Journal of Contemporary Hospitality Management, 9(1): 13-20. https://doi.org/10.1108/09596119710157522.

Lwiza, D.R.B., \& Nwankwo, S. (2002). Market-driven transformation of the banking sector in Tanzania. International Journal of Bank Marketing, 20(1), 38-49. https://doi.org/10.1108/02652320210415971.

Mahmoud, M.A., Blankson, C., Owusu-Frimpong, N., Nwankwo, S., \& Trang, T. P. (2016). Market orientation, learning orientation and business performance: The mediating role of innovation. International Journal of Bank Marketing, 34(I5), 623-648. doi.org/10.1108/IJBM-04-2015-0057

Marginson, S. (2004). Competition and markets in higher education: A 'glonacal' analysis", Policy Futures in Education, 2(2). doi.org/10.2304/pfie.2004.2.2.2.

Maringe, F. (2004). Vice Chancellor's perceptions of university marketing: A view from universities in a developing country." Higher Education Review, 36(2), 3-68. https://eprints.soton.ac.uk/id/eprint/41025.

Maringe, F. (2005). Interrogating the crisis in higher education marketing: The CORD model. International Journal of Educational Management, 19(7), 564-578. https://doi.org/10.1108/09513540510625608.

Maringe, F. (2006). University and course choice: Implications for positioning, recruitment and marketing. International Journal of Educational Management, 20(6), 466-479. doi.org/10.1108/09513540610683711.

Maydeu-Olivares, A., \& Lado, N. (2003). Market orientation and business economic performance: A mediated model. International Journal of Service Industry Management, 14(3), 284-309. doi.org/10.1108/09564230310478837.

McGrath, J. M. (2002). Attitudes about marketing in higher education: An exploratory study. Journal of Marketing for Higher Education, 12(1), 114.doi.org/10.1300/J050v12n01_01.

Meitamei, L. (2010). Market orientation and performance of a bank: The case of Twiga Bancorp Limited. A Dissertation Submitted in (Partial) Fulfilment of the 
Requirements for the Degree of Master of Business Administration (Finance) of the University of Dar es Salaam. http://41.86.178.4/jspui/bitstream/1/313/1.

Momrak, E.M. (2012). Effects of market orientation on business performance: Environmental moderators, effectiveness and efficiency mediators and the role of firm capabilities. Thesis Master of Science in Business and Administration Specialization in Marketing, Buskerud University College, Hønefoss. https://brage.bibsys.no/xmlui/handle/11250/142133.

Moorman, C., \& Rust, R.T. (1999). The role of marketing. Journal of Marketing, 63(Special Issue), 187-197. DOI: 10.2307/1252111.

Mpanju, A.K. (2012). The impact of foreign direct investment on employment creation in Tanzania." ZENITH International Journal of Business Economics \& Management Research 2(1):14. http:/ / zenithresearch.org.

NACTE (nd). How to discover our quality: Handbook, for quality monitoring in technical education in Tanzania.

Narver, J.C., \& Slater, S.P. (1990). The effect of a market orientation on business profitability. Journal of Marketing, 54 (October), 20-35. DOI: 10.2307/1251757.

Ndyali, L. (2016). Higher education system and jobless graduates in Tanzania. Journal of Education and Practice, 7(4), 6. https://www.iiste.org.

Newman. C.M. (2001). The current state of marketing activity among higher education institutions. Journal of Marketing for Higher Education, 12(1). doi/abs/10.1300/J050v12n01_02.

Nguyen, N., \& LeBlanc, G. (2001). Image and reputation of higher education institutions in students' retention decisions." International Journal of Educational Management, 15(6), 303-311. https://doi.org/10.1108/EUM0000000005909

Nicolescu, L. (2009). Applying marketing to higher education: scope and limits. Management and Marketing, 4(2), 35-44. http://www.managementmarketing.ro/pdf/articole/134.pdf

Niculescu, M., Xu, B., Hampton, G.M., \& Peterson, R.T. (2013). Market orientation and its measurement in universities. Administrative Issues Journal: Education, Practice and Research, 3(2). DOI: 10.5929/2013.3.2.2.

Njawa, J.J. (2015). The effects of advertising on organizational performance: A case study of TIGO telecommunication network. Unpublished dissertation Submitted in Partial/Fulfilment of the Requirements for Award of the Degree of Master of Business Administration (MBA) of Mzumbe University. http://hdl.handle.net.

ole Gabriel, E. (2005). An assessment of value co-creation and delivery systems in the higher education sector of Tanzania. African Journal of Finance. https://edenconsult.net.

Polat, G., \& Umit, D. (2010). Marketing management functions of construction companies: Evidence from Turkish contractors. Journal of Civil Engineering and Management, 16(2), 267-277. doi/abs/10.3846/jcem.2010.31 
Pope, J.A., Isely, E.S., \& Asamoa-Tutu, F. (2009). Developing a marketing strategy for non-profit organizations: An exploratory study. Journal of Nonprofit and Public Sector Marketing, 21(2), 184-201. doi.org/10.1080/10495140802529532

Rindfleish, J.M. (2003). Segment profiling: Reducing strategic risk in higher education managements. Journal of Higher Education Policy and Management, 25(2), 147-159. doi.org/10.1080/1360080032000122624.

Ross, M., Grace, D., \& Shao, W. (2013). Come on higher ed. ... get with the programme! A study of market orientation in international student recruitment. Educational Review, 65(2), 219-240. doi.org/10.1080/00131911.2012.659656

Rotfeld, H.J. (2008). The largest segments that should not be served: Higher education marketing serving the growing slacker segment. Journal of Consumer Marketing, 25(6), 378-380. doi.org/10.1108/07363760810902512.

Rowley, J. (2003). Retention: rhetoric or realistic agendas for the future of higher education. International Journal of Educational Management, 17(6), 248-253, https://doi.org/10.1108/09513540310487578.

Šályováa, S.J., Petrovičováa, T., Nedelováa, G., \& Ďad’oa, J. (2015). Effect of marketing orientation on business performance: A study from Slovak foodstuff industry. Procedia Economics and Finance, 34, 622-629. https://core.ac.uk/download/pdf/82801284.

Saunders, M., Lewis, P., \& Thornhill, A. (2007). Research Methods for Business Students (4th Ed). New York: Prentice Hall.

SeyedJavadin, S., Rayej, H., Yazdani, H., Estiri, M., \& Ali, S.A. (2012). How organizational citizenship behaviour mediates between internal marketing and service quality: The case of Iranian Gas Company. International Journal of Quality \& Reliability Management, 29(5), 512-530. https://doi.org/10.1108/02656711211230508

Sharp, B. (1991). Marketing orientation: More than just customer focus. International Marketing Review, 8 (4). https://doi.org/10.1108/EUM0000000001540.

Shepherd, I.D.H. (2008). The application of marketing thinking to student retention. Planet, 19(1), 26-30. doi.org/10.11120/plan.2008.00190026.

Singumlanji, L.I. (2009). The role of marketing in sustainable water and sanitation project. The case of MORUWASA. Unpublished dissertation Submitted to Mzumbe University. http://hdl.handle.net.

Stachowski, C.A. (2011). Educational marketing: A review and implications for supporting practice in tertiary education. Educational Management Administration and Leadership, 39(2), 186-204. doi.org/10.1177/1741143210390056.

Starck, K., \& Hossein, S. Z. (2013). Marketing within higher education institutions: A case study of two private Thai universities: Master thesis in business administration. Mälardalen University, the School of Business, Science and Engineering EFO704. http://www.divaportal.org/smash/get/diva2:625908/fulltext02.pdf 
Svenson, G., \& Wood, G. (2007). Are university students really customers? When illusion may lead to delusion for all!. International Journal of Educational Management, 2(1), 17-28, https://doi.org/10.1108/09513540710716795.

Tabaku, E., \& Mirela, M. (2013). An Overview of marketing means used by nonprofit organizations: A detailed overview of NPOs operating in the district of Elbasan. Journal of Marketing and Management, 4 (2), 78-95. https://studyres.com/doc/5019039

Tajeddini, K., Trueman, M., \& Larsen, G. (2006). Examining the effect of market orientation on innovativeness. Journal of Marketing Management, 22, 5-6. doi.org/10.1362/026725706777978640

Tanzania Breweries Limited (TBL). (2015). Annual report. Retrieved from https://www.ab-inbev.com/.../reports.

Tanzania Breweries Limited (TBL). (2016). Annual report. Retrieved from https://www.ab-inbev.com/.../reports.

Tanzania Breweries Limited. (2008). Annual report and accounts. Retrieved from https://www.ab-inbev.com/.../reports.

Tanzania Cigarette Company (TCC). (2015). Annual report. Retrieved from https://www.dse.co.tz/.../TCC-\%20Annual\%20Report\%.

Tanzania Commission for Universities (TCU), (2014). Quality assurance: General guidelines and minimum standards for provision of university education in Tanzania $\left(2^{\text {nd }} \mathrm{ed}\right)$, Dar es Salaam, Tanzania.

United Nations Development Programme. (2014). Sustainable development goals 2030. https://sustainabledevelopment.un.org/?menu=1300.

United Republic of Tanzania. (2000). Education in a global era: Challenges to equity, opportunity for diversity, Paper Presented at the Fourteenth Conference of Commonwealth Education Ministers (CCEM) Halifax, Nova Scotia, Canada, 27 -30 .

United Republic of Tanzania. (2005). University Act. Dar es Salaam: Government Printer.

United Republic of Tanzania. (2010). Higber education development programme 20102015, Ministry of Education and Vocational Training, Public Administration.

United Republic of Tanzania. (2011). Tanzania, beyond primary education, the quest for balanced and efficient policy choices for human development and economic growth, Dar es Salaam, Tanzania.

United Republic of Tanzania. (2013). Government budget for financial year 2012/2013 Citizens' Budget Edition, Ministry of Finance.

United Republic of Tanzania. (2014). Government budget for financial year 2013/2014 Citizens' Budget Edition, Ministry of Finance.

United Republic of Tanzania. (2014). Tanzania development vision 2025: National key result area education-big results now. Dar es Salaam: Ofisi ya Rais Tume ya Mipango. 
United Republic of Tanzania. (2014). The study on national skills development to Facilitate Tanzania to become a strong and competitive economy by 2025. President's Office, Planning Commission, Dar es Salaam Tanzania.

United Republic of Tanzania. (2015). Speech by the Minister for Finance Hon. Saada Mkuya Salum (MP) Introducing to the National Assembly: The Estimates Of Government Revenue and Expenditure for Fiscal Year 2015/2016. Government Printer.

United Republic of Tanzania. (2016). National five year development plan, 2016/17 2020/21, Ministry of Finance and Planning, Dar es Salaam, Tanzania.

United Republic of Tanzania. 2013. University act general regulations. Dar es Salaam: Government Printer.

Vodacom Tanzania Public Limited Company. (2017). Vodacom Tanzania Public Limited Company annual report for the year ended 31 March 2017. Retrieved from https://vodacom.co.tz/en/investorrelation/index/investorrelation.

Voon, B. H. (2006). Linking a service-driven market orientation to service quality: Managing service quality. An International Journal, 16(6), 595-619. https://doi.org/10.1108/09604520610711927.

Voon, B.H. (2008). SERVMO: A measure for service-driven market orientation in higher education. Journal of Marketing for Higher Education, 17(2), 216-237. doi.org/10.1080/08841240801912583.

Wiessing, M. (2015). National Microfinance Bank Plc investors' presentation. https://www.nmbbank.co.tz/investor-relations-nmb/...presentations.

Young, L. (2005). Marketing the professional services firm: Applying the principles and the science of marketing to the professions. The Atrium, Southern Gate, Chichester, West Sussex PO19 8SQ, England: John Wiley \& Sons Ltd.

Zebal, M.A., \& Goodwin, D. R. (2012). Market orientation and performance in private universities. Marketing Intelligence and Planning, 30(3), 339-357. https://doi.org/10.1108/02634501211226302

Zhang, L., Kara, A., Spillan, J.E \&, Mintu-Wimsatt, A. (2017). Exploring market orientation among Chinese small and medium-sized enterprises. Chinese Management Studies, 1(4), 617-636. https://doi.org/10.1108/CMS-08-2016-0158. 